\title{
ARBITRATORS' EX PARTE CONSULTATIONS AND INVESTIGATIONS
}

Ex parte investigations and consultations by arbitrators with third persons without notice to the parties to the submission is a recurring problem in arbitrations. It is the purpose of this Comment to examine and discuss recent developments of the California law ${ }^{1}$ on this subject.

The California Arbitration Act ${ }^{2}$ does not deal explicitly with ex parte activities of arbitrators, but it does provide for the vacation of the award for "misconduct"3 on the part of the arbitrators. It is as misconduct that ex parte problems are presented to the courts and the term is left to judicial defimition. The leading California case is Sapp v. Barenfeld, ${ }^{4}$ in which a dispute arose out of a building contract and was submitted to arbitration for resolution. After informal learings, wherein the arbitrators deternined that the work did not conform to specifications of the contract, the arbitrators consulted a skilled cost appraiser for an estimate of the labor and material cost for remedying the defects. The estimate was checked with other sources and adopted as the basis for the establishment of damages in the award. No notice of the consultation was given the parties, nor were they given an opportunity to dispute or examine the information so obtained. After finding that the award was the result of the arbitrators' own judgment, the court refused to find error in the procedure adopted or misconduct on the part of the arbitrators. The court discussed the problem as follows: ${ }^{5}$

\begin{abstract}
Although a hearing is required on disputed questions of fact, arbitrators may inform themselves further by privately consulting price lists, examining materials and receiving cost estimates. ... This procedure may be ex parte, without notice or hearing to the parties, for "it is entirely proper for arbitrators, in a case requiring it, to obtain froin disinterested persons of acknowledged skill such information and advice in reference to technical questions submitted to thein, as may be necessary to enable them to come to correct conclusions, provided that the award is the result of their own judgment after obtaining such information."... It is immaterial whether the subject of the appraisal is the only matter in dispute or is a part of a broader submission.
\end{abstract}

The rationale of the Sapp case was applied to another case involving ex parte consultation recently decided by the supreme court, Griffith Co. v. San Diego College for Women. ${ }^{6}$ In the Griffith case a construction contract provided for arbitration of disputes arising thereunder in accordance with the Standard Form of Ar-

1 For full discussion and analysis of labor and commercial arbitration in California under the arbitration statute see Kagel, Labor and Commercial Arbitration Under the California Arbitration Statute, 38 CAIIF. L. Rev. 799 (1950).

2 Cal. Code Crv. Proc. \$\$ 1280-93.

3 CAI. CODE Crv. Proc. $\$ 1288$ provides in part: "In either of the following cases the superior court ... must make an order vacating the award, upon application of any party to the arbitration: .... (c) Where the arbitrators were guilty of misconduct, in refusing to postpone the hearing, upon sufficient cause shown, or in refusing to hear evidence, pertinent and material to the controversy; or of any other misbehaviors, by which the rights of any party have been prejudiced. (d) Where the arbitrators exceeded their powers, or so imperfectly executed them, that a mutual, final and definite award, upon the subject matter submitted, was not made."

434 Cal. 2d 515, 212 P.2d 233 (1949).

5 Id. at 521, 212 P.2d at 238. (Citations omitted; see note 11 infra.)

$645 \mathrm{Cal}$. 2d 501, 289 P.2d 485 (1955). This decision, which was issued after a rehearing, is identical with the earhier one, Griffith Co. v. San Diego College for Women, 286 P.2d 3 (Cal. 1955), except for the addition of the dissent by Justice Edmonds. Plaintifi Griffith Company's second petition for rehearing was denied. Griffith Co. v. San Diego College for Women, 45 Cal. 2d 501, 517, 289 P.2d 476, 485 (1955). 
bitration Procedure of the American Institute of Architects ${ }^{7}$ and the prevailing arbitration law. After the chairman of the tripartite arbitration panel had made a tentative decision, he consulted an unnamed and undisclosed attorney regarding its legal aspects. ${ }^{8}$ After the chairman had been advised by the attorney, another member of the panel concurred in the chairman's opimion and it became the basis of the award. While the chairman had informed his fellow arbitrators of his intention to consult an attorney, he had not notified the parties of the actual consulta tion. In affirming the judgment confirming the award, the court held that the actions of the chairman did not constitute nnisconduct under the arbitration statute on the authority of the passage from the Sapp case quoted above. ${ }^{2}$ The court emphasized that the chairman had reached his opinion independently and that there had been no showing that the attorney consulted was not disinterested. After a rehearing, Justice Edmonds dissented on the ground that such consultation denied the party a fair hearing. ${ }^{10}$

The Sapp and Griffith cases seem to leave the California law regarding ex parte investigations and consultations by arbitrators as follows: Ex parte consultations

7 The significant rules of the Standard Form are as follows: "11. Conduct of Hearing. The hearing shall be so conducted that the complaining party and its witnesses shall be heard and may be subject to questioning by the other party or by its counsel, and the defending party and its witnesses sball be heard and may be subject to questioning by the other party or by its counsel. ... When all pertinent and material evidence has been submitted by the parties, the arbitrators shall formally close the hearing and proceed in private to their deliberations prior to making the award. ... 12. Submission of Proofs. Proof shall be taken in the prescnce of the parties and in the presence of all the arbitrators, unless a party has absented itself by its own fault, after due notice that such proofs will be taken, or unless the parties have mutually authorized such proofs to be taken in their absence. Proofs to be submitted to the arbitrators may comprise testimony by the parties and by their witnesses, documents and exhibits, affidavits and such other material and pertinent evidence as the parties offer and as the arbitrators deem admissible. Proofs may be taken by the arbitrators at any time during the proceedings by making inspection of premises or materials or by ordering tests made of materials and by receiving such other evidence as they may require...." Brief for Appellant, pp. 31, 32, Griffith Co. v. San Diego College for Women, 45 Cal. 2d 501, 289 P.2d 485 (1955). The significance of these rules lies in the fact that when a submission directs that certain rules shall be followed the arbitrators must follow them or the award will be invalid. E.g., Christenson v. Cudahy Packing Co., 198 Cal. 685, 691, 247 Pac. 207, 210 (1926); Drake v. Steim, 116 Cal. App. 2d 779, 785, 254 P.2d 613, 617 (1953).

8 As the chairman put it in his affidavit, he wished to determine that his opinion "was not grossly erroneous as far as the law was concerned ...." Griffith Co. v. San Diego College of Women, $45 \mathrm{Cal}$. 2d 501, 506, $289 \mathrm{P} .2 \mathrm{~d} \mathrm{476,} 478$ (1955). The chairman interpreted a clause in the construction contract that "the law of the place of the building shall govern the construction of [the] ... contract" as requiring him to follow the California law regarding the burden of proof of damages and proximate cause in the arbitration proceedings. Id. at 514, 289 P.2d at 483. Accordingly it appears the chairman sought legal advice on Cahfornia Civil Code $\$ \$ 3300$ and 3301 and a case applying them, Austin v. Roberts, 130 Cal. App. 328, 20 P.2d 97 (1933).

It might be argued that the aforementioned clause in the contract did not apply to the submission to arbitration, which was exphicitly to be governed by the Standard Form of Arbitration Procedure of the American Institute of Architects, which in turn makes no mention of "prevailing law," The district court of appeal also pointed out that the law as announced in the award was arguable. Griffith Co. v. San Diego College for Women, 280 P.2d 203, 213 (Cal. App. 1955). This was not an issue on review, however, as the merits of the award were not before the court. Id. at 212 .

${ }^{9}$ See text at note 5 supra.

10 In his dissent Justice Edmonds stated that under the principles of fair trial the parties to the submission were entitled to a full, fair, and unbiased hearing. "If arbitration is to lave the place in the adininistration of justice to which it is entitled, it must be conducted in accordance with the same rules of law which apply to judicial proceedings, insofar as the integrity of decision is concerned." 45 Cal. $2 \mathrm{~d}$ at 517,289 P.2d at 485. 
and investigations by arbitrators are sanctioned if the person consulted is disinterested and of acknowledged skill, and the burden of proof in showing that he is otherwise is on the complainant; the subject of the inquiry must be undisputed facts or questions of law; and the decision of the arbitrator must be his own. From the standpoint of the complaining party, the difficulties with such a set of rules are manifest. If the identity of the person consulted can be kept secret, it is virtually impossible for a complaining party to show violation of the other rules. If the ex parte activities and the subject matter of the inquiries need not be disclosed to the parties before the award, the complaining party is denied an opportunity to question, answer, or rebut the information so received, regardless of its materiality to the issue under submission.

The results reached in the Sapp and Griffith cases appear to have their basis in the application to arbitrators of rules of conduct and the freedom of action usually associated with appraisals. ${ }^{11}$ An appraisal ${ }^{12}$ is generally a reference to a third party

11 An analysis of the cases and authorities cited and relied upon by the court in the Sapp and Griffith cases for the portion of the opinions quoted in the text at note 5 supra indicates the application of appraisal doctrine to an arbitration. Eight of the twelve cases cited were appraisal situations and discussed the law applicable thereto: Omaha v. Omaha Water Co., 218 U.S. 180 (1910) ; Dore v. Southern Pac. Co., 163 Cal. 182, 124 Pac. 817 (1912); Foster v. Carr, 135 Cal. 83, 67 Pac. 43 (1901); California Annual Conference of M.E. Church v. Seitz, 74 Cal. 287, 15 Pac. 839 (1887); Rives-Strong Bldg., Inc. v. Bank of Am., 50 Cal. App. 2d 810, 123 P.2d 942 (1942); Bangor Savings Bank v. Niagara Fire Ins. Co., 85 Me. 68, 26 Atl. 991 (1892); Hegeburg v. New England Fish Co., 7 Wash. 2d 509, 110 P.2d 182 (1941); Gord v. F. S. Harmon \& Co., 188 Wasl. 134, 61 P.2d 1294 (1936). Two of the cases involved situations where the parties intended the arbitrator to use his own expert knowledge: Liggett v. Torrington Bldg. Co., 114 Conn. 425, 158 Atl. 917 (1932); Koepke v. E. Liethen Grain Co., 205 Wis. 75, 236 N.W. 544 (1931). One case, Twin Lakes Reservoir \& Canal Co. v. Platt Rogers, Inc., 112 Colo. 155,147 P.2d 828 (1944), involved a submission where there had been prior agreement among the parties to the arbitrator's $e x$ parte consultation. The facts of the remaining case, Sinuons $v$. Mills, 80 Cal. 118, 22 Pac. 25 (1889), are not clear.

The court's references to the works of Sturges and Mechem are no more helpful. STURGES, Contanerctal ARBItrations and Awards 495 (1930), consists of a discussion of the leading case on arbitrators' ex parte investigations, Stefano Berizzi Co. v. Krausz, 239 N.Y. 315, 146 N.E. 436 (1925). In that case Judge Cardozo, speaking for the court, held that an ex parte investigation directed to the issue involved in the arbitration was misconduct. He added by way of dictum: "We do not mean, of course, that an award will be vitiated by investigations in the absence of the parties if directed toward facts of trifing importance or facts of such a nature as to preclude reasoneble contest. This may imclude views or measurements or the ascertainment of physical conditions notorious and permanent." Id. at 320, $146 \mathrm{N.E}$. at 438. (Emphasis added.) Perhaps it is significant that the California court declined to adopt Cardozo's reasoning exphicitly.

The reference to MECHEM, AGENCY 229 (2d ed. 1914), is a discussion of delegation of authority to an agent. The authorities cited by Mechem for the statement that "it is entirely proper for arbitrators, in a case requiring it, to obtain from dismterested persons of acknowledged skill such imformation and advice in reference to technical questions submitted to them, as may be necessary to enable them to come to correct conclusions, provided that the award is the result of their own judgment after obtaining such information. ..." consist of four English and one early Rhode Island case. Professor Isaacs has pointed out the conceptual difference between the English and American view of arbitrators and the resulting practical differences in application. The English theory of arbitration is predieated on the premise that an arbitrator is an agent of the parties. The American theory is based on the premise that an arbitrator acts in a judicial capacity rather than in one of agency. See Isaacs, Two Views of Commercial Arbitration, 40 HARv. L. REv. 929 (1927).

12 The devclopment of the doctrine of appraisal indicates the curious interrelation of judicial flexibility and the rigidity of stare decisis. Arbitration encountered hostility from the common law courts which is traceable to Vynior's Case, 8 Co. Rep. 80a, 81b, 77 Eng. Rep. 595, 597 (K.B. 1609). There the court refused to enforce specifically an executory agreement to arbi- 
to fix by his judgment the price, quantity, or quality of a product or material.13 Examples of submissions that have been considered appraisals in California are determinations of the value of extra work done under a contract, ${ }^{14}$ valuations of land and buildings in sales and option contracts, ${ }^{15}$ valuations of services, ${ }^{10}$ valuations of losses covered by fire insurance policies, ${ }^{17}$ and partition determinations. ${ }^{18}$ An arbitration on the other hand is generally a formal proceeding in which a determination is made on the basis of submitted evidence rather than on the basis of the arbitrator's own opinion or judgment. Appraisals have been characterized as ministerial proceedings to avoid controversies, ${ }^{19}$ while an arbitration, it is said, presumes a controversy or dispute. ${ }^{20}$

trate on the grounds that it was contrary to public policy to oust the jurisdiction of the courts and that a court of equity was unable to execute a decree which would result in the specific performance of the agreement. See CoIEN, ComoMercial ARBITratTon AND THE LAW 103-27 (1918). The early California cases assumed the line of authority from Vynior's Case to be settled law and arbitration agreements were deried specific performance. Holmes v. Richet, $56 \mathrm{Cal} .307$ (1880) ; W. H. Blodgett Co.v. Bebe Co., 190 Cal. 665, 214 Pac. 38 (1923).

The rule of Vynoir's Case was modified in 1855 by the reasoning in Scott v. Avery, 25 L.J. Ex. 308, 5 H.L.C. 811, 10 Eng. Rep. 1121 (H.L. 1856). See ConEN, supra at 180-204; Hogg, The LAw of ARBitration 48-55 (1936). There the agreement which was sought to be enforced was to submit the valuation of a subject of an insurance policy to an impartial board of arbitrators when the insured and insurer could not agree. The court distinguished a valuation or appraisement from an arbitration by poimting out that the former involved a determination of facts that were but imcidental to the basic rights under the contract. Since the basic rights under the contract remained the province of the courts, to give recogrition to the appraisement would not oust the jurisdiction of the court. It was also in Scott v. Avery that Lord Camphell pointed out that the rule of Vynior's Case was the product of judicial jealousy rather than judicial reasoming. He stated that the rule arose at a time when "the emoluments of the Judges depended mainly or almost entirely upon fees [and] ... there was a great competition to get as much as possible of bitigation into Westminster Hall [and in consequence] . . . they had great jealousy of arbitrations." Scott v. Avery, 25 L.J. Ex. 308, 313, 5 H.L.C. 811, 10 Eng. Rep. 1121 (H.L. 1856).

Along with other jurisdictions (see Sturges, Comamerctat Arbitrations and Awards $\$$ 712 (1930)), the Califorma courts also adopted the rationale of Scott v. Avery as a means of giving effect to appraisal agreements while averred public policy continued to dictate the invalidity of executory arbitration agreements. W. H. Blodgett Co. v. Bebe Co., $190 \mathrm{Cal}$. 665, 214 Pac. 38 (1923) ; Califormia Annual Conference of M.E. Church v. Seitz, 74 Cal. 287, 15 Pac. 839 (1887); Old Saucelito Land and Dry Dock Co. v. Commercial Umion Assurance Co., 66 Cal. 253, 5 Pac. 232 (1884); Loup v. California So. R.R., 63 Cal. 97 (1883); Holmes v. Richet, 56 Cal. 307 (1880).

By the time the California Arbitration of Act of 1927 was enacted, public policy towards arbitration had changed and courts openly announced that arbitration was a favored device. The Arbitration Act now makes statutory arbitration agreements irrevocable, CAr. CODE CIV. Proc. \$ 1280, and provides for specific performance of the agreement, CAx. CodE Crv. Proc. \$1282. See Kagel, Labor and Commercial Arbitration Under the California Arbitration Statute, 38 CALTF. L. REV. 799, 806 (1950), for a discussion of differences between common law and statutory arbitrations.

I3 See STURGES, supra, for an extensive discussion of the distinctions between appraisals and arhitrations.

14 Davisson v. East Whittier Land \& Water Co., 153 Cal. 81, 96 Pac. 88 (1908); Loup v. California So. R.R., 63 Cal. 97 (1883) ; Holmes v. Richet, 56 Cal. 307 (1880).

15 Dore v. Southern Pac. Co., 163 Cal. 182, 124 Pac. 817 (1912); California Annual Conference of M.E. Cliurch v. Seitz, 74 Cal. 287, 15 Pac. 839 (1887).

${ }^{16}$ Roche v. Baldwin, $135 \mathrm{Cal}$. 522, 65 Pac. 459 (1902).

17 Stockton Combimed Harvester \& Agricultural Works v. Glens Falls Ins. Co., 98 Cal. 557, 33 Pac. 633 (1893); Old Saucelito Land and Dry Dock Co. v. The Commercial Union Assurance Co., $66 \mathrm{Cal} .253,5$ Pac. 232 (1884).

18 Gonzalez v. Gonzalez, 174 Cal. 588, 163 Pac. 993 (1917).

19 See Sturges, Comacerctat Arbitrattons aNd Awards, \$8 7-12 (1930).

20 Ibid. The propositions relied upon by the courts to distinguish arbitrations from appraisals have reflected the results of the distinction rather than the reason for it. To say that an 
The most significant difference between the two forms of submission are the different rules of law and standards of conduct which govern each proceeding. ${ }^{21}$ An appraisal is an informal proceeding with few rules. ${ }^{22}$ Ex parte activities on the part of the appraiser are sanctioned and even expected. An arbitration presupposes a formal hearing ${ }^{23}$ with the necessary rules to insure its fairness: notice to the parties; $;^{24}$ presentation of evidence ${ }^{25}$ and the opportunity for the parties to present their own evidence and to cross-examine, rebut, and answer the evidence of others. ${ }^{26}$

While the distimctions between these two submissions have been criticized as illogical and unnecessary, ${ }^{27}$ and suggestions have been made with varying success to equate the appraisal submission to an arbitration, ${ }^{28}$ it would seen that in Cah-

appraisal is a proceeding to avoid controversy while an arbitration presumes a controversy is specious when the agreement to appraise becomes operative only in the case of disagreement or dispute. Practically, an appraisal is far from ministerial. In a contract to purchase property the price to be set by appraisement may be one of the most important terms, as is the loss to be reimbursed by the insurer, the rental to be paid by the lessee, or the remuneration to be paid for services. Another distinction sometimes made is that the subject of an arbitration is in the nature of a civil cause of action. Dore v. Southern Pac. Co., 163 Cal. 182, 124 Pac. 817 (1912). This requirement appeared in the early California codifications but the statute no longer makes that distinction (CAL. CODE Crv. Proc. \$ 1281) and all controversies would seem to be arbitrable today. Kagel, Labor and Commercial Arbitration Under the California Arbitration Statute, 38 CAIrF. L. Rev. 799, 807 (1950). See note 21 infra.

21 This distinction between appraisal and arbitration has not uniformly been recognized. The Mimnesota Supreme Court exemplified the other approach when it held that an appraisal board "is a quasi court, subject to the principles governing common-law arbitration. Such board should sit in a body, and receive evidence offered by the respective parties, submitting the same to the usual tests of cross-examination. ... [I]ts individual members are prohibited from privately collecting evidence from different sources .... [S] uch board is not selected for the purpose of seeking evidence secretly, and determining the amount of the loss by reason of such personal knowledge." Christianson v. Norwich Union Fire Ins. Soc., 84 Minn. 526, 530, 88 N.W. 16, 18 (1901). See also Citizens Bldg. v. Western Union Tel. Co., 120 F.2d 982 (5th Cir. 1941); Insurance Co. of No. Am. v. Hegewald, 161 Ind. 631, 66 N.E. 902 (1903) ; Koopman v. Farmers' Hail Ins. Ass'n, 209 Iowa 958, 229 N.W. 221 (1930) ; Dufresne v. Marine Ins. Co., 157 Minn. 390, 196 N.W. 560 (1923) ; Holt v. Williams, 210 Mo. App. 470, 240 S.W. 864 (1922).

22 See Sturges, Comprerciat Arbitration aNd Awards \$\$ 8-11 (1930).

23 Cat. Cgde Civ. Proc. $\$ 1286$.

24 Although there is no exphicit requiremeut in the statute that notice be given, such a requirement was deemed to be imphed in the earlier 1872 statute. Curtis v. Sacramento, $64 \mathrm{Cal}$. 102, 28 Pac. 108 (1883) ; see Sapp v. Barenfeld, 34 Cal. 2d 515, 212 P.2d 233 (1949).

25 Cax. Code Crv. Proc. $\$ 1286$.

26 Gonzalez v. Gonzalez, 174 Cal. 588, 163 Pac. 993 (1917); Stockton Coinbined Harvester \& Agricultural Works v. Glen Falls Ins. Co., 98 Cal. 557, 33 Pac. 633 (1893) ; California Annual Conference of M.E. Church v. Seitz, 74 Cal. 287, 15 Pac. 839 (1887) ; Curtis v. Sacramento, 64 Cal. 102, 28 Pac. 108 (1883) ; Thompson v. Newman, 36 Cal. App. 248, 171 Pac. 982 (1918); Stockwell v. Equitable Fire and Marine Ins. Co., 134 Cal. App. 534, 25 P.2d 873 (1933). See also Sapp v. Barenfeld, 34 Cal. 2d 515, 212 P.2d 233 (1949).

276 WIIJISTON, Contracts 5379 (1936); see Kagel, Labor and Commercial Arbitration Under the California Arbitration Statute, 38 CALTF. L. REv. 799, 814-17 (1950); note 21 supra.

28 The experience of New York has been interesting in its attempts to bring appraisal within the arbitration statute.

The New York arbitration statute provides that the subject of an arbitration is "any controversy ... which may be the subject of an action ... " N.Y. Crv. Prac. Acr \& 1448. On the basis of that wording the New York courts refused to include appraisals of any fact affecting the contractual rights of the parties to be withm the purview of the arbitration law. E.g., Buffalo \& E. Ry. v. Amalgamated Ass'n of Street \& Elec. Ry. Employees, 250 N.Y. 275, 165 N.E. 291 (1929); Fletcher v. Nicholas, 237 N.Y. 440, 143 N.E. 248 (1924).

As a result of this long line of cases distinguishing and refusing to place appraisals within the mechanics of the arbitration law, the Association of the Bar of the City of New York was instrumental in the enactment of an amendment to the arbitration statute which was intended 
fornia the distinction remains under Bewick v. Mecham, ${ }^{29}$ where appraisals were held not to be within the purview of the Arbitration Act. ${ }^{30}$ The Sapp and Griffith decisions ignored Bewick, and in treating arbitrations as appraisals thereby blurred the distinctions between them. ${ }^{31}$

\section{Ex Parte Investigations and Consultations as Official Notice}

It is submitted that the problem of ex parte consultations and investigations made by arbitrators without notice to or consent of the parties, as well as the arbitrator's use of his own knowledge, is essentially the problem of judicial or official

to bring appraisals within the statute. JUDICIAI COUNCIC OF NEW YoRK, SEVENTEENTE ANNUAI REPORT, Legislative Document No. 26, at 236 (1951); Association of THE BAR of THE CITY of NEW YoRK, YeAR BOoK 315 (1940) (Annual Report of the Special Committee on Arbitration for 1939-1940).

The amendment provided that "Such submission or contract may include questions arising out of valuations, appraisals or other controversies which may be collateral, incidental, precedent or subsequent to any issue between parties." N.Y. Crv. PRAC. ACr \$ 1448, amend. I. 1941, c. 288. It was felt that this would make the arbitration rules applicable to appraisals and in effect fill the gap in the arbitration system caused by the doctrine of appraisal. Note, 5 ARs. J. 237 (1941).

Judicial interpretation of the amendment did not give effect to such intention. The "subject of an action" test was still applied and appraisals were demied statutory arbitration treatment when they stood alone. E.g., Syracuse Savings Bank v. Yorkshire Ins. Co., 301 N.Y. 403, 94 N.E.2d 73 (1950); Stern v. Stern, 285 N.Y. 239, 33 N.E.2d 689 (1941). The amendment was effective to the extent that it provided for the applicability of the statutory rules when the appraisal was but incidental and related to the main issue in a controversy, so long as the main issue itself was arbitrable. Kallus v. Ideal Novelty \& Toy Co., 292 N.Y. 459, 55 N.E.2d 737 (1944); see Association of the Bar of the City of NEW York, Year Boor 216-17 (1945) (Annual Report of the Special Committee on Arbitration, 1944-1945).

In 1952 the statute was amended again so that the clause reads: "Such submission or contract may include questions arising out of valuations, appraisal or other controversies which may be collateral, incidental, precedent or subsequent to or independent of any issue between parties." N.Y. Crv. PrAC. ACT \& 1448, amend. L. 1952, c. 757. (Italicized portion is the amendment.) Again hopes were high that valuations and arbitrations which were independent of any issue hetween the parties would be covered by the arbitration statute. Note, 7 ARB. J. (n.s.) 87 (1952). But a recent New York case makes it elear that the New York Court of Appeals still will not effectuate a conversion of an appraisal into an arbitration. The court said: "It may, perhaps, be desirable to provide a procedure whereby the insured may obtain specific enforcement, as against the insurance company, of the agreement for appraisal. If such be its aim, the legislature may accomplish it hy a statute clearly and specifically drawn for that purpose. A court cannot, however, read that design into the statute here involved [N.Y. Civ. Prac. Act \$ 1448], particularly when the result would be, not merely to permit the enforcement of such appraisal provisions, but to effect the wholesale importation, into appraisement practice, of the entirely different procedure governing arbitration." In the matter of Delmar Box Co., 309 N.Y. $60,67,127$ N.E.2d 808, 813 (1955). For a criticism see Evans, Annual Survey of American Law, 1955-Insurance, 31 N.Y.U.L. REv. 557, 560 (1956).

2926 Cal. 2d 92, 156 P.2d 757 (1945).

30 Bewick v. Mecham involved a lease containing an option to purchase "at a price and terms then to be [in the event of failure of the partics to agree] ... fixed by arbitration...." Id. at $94,156 \mathrm{P} .2 \mathrm{~d}$ at 759 . Although the parties apparently meant to set up an arbitration under the arhitration statute, the court held that since it was not contemplated by the parties that the arbitrators should decide any "controversy" but rather that their task was to make a valuation of the land and fix the purchase price, this evaluation did not constitute an arbitration under the arbitration statute.

31 Of course the parties may, by an explicit expression of their intent, apply arbitration rules to appraisals. Dore v. Southern Pac. Co., 163 Cal. 182, 184, 15 Pac. 817, 819 (1912). But there was no indication in either $S a p p$ or Griffith that the parties intended to relax the procedural rules of arbitrations for the application of appraisal procedure. 
notice. An arbitration is a quasi-judicial proceeding. ${ }^{32}$ Disputes and questions between parties are resolved and the award can be made the judgment of the court under a statutory proceeding. ${ }^{33}$ The parallel between arbitrators, judges, and other officials who adjudicate is even closer if one looks through the form of the usual tripartite panel in an arbitration. Generally the submission agreement provides that each party select one "arbitrator" and those two select the third, who acts as chairman. In practice this procedure results in the nominees acting as champions of their respective nominators; thus, in effect, the chairman is the true arbitrator. ${ }^{34}$ As in admimistrative adjudication, ${ }^{35}$ the technical rules of procedure and evidence are not applicable to arbitrations. ${ }^{36}$ Yet the courts reiterate that the fundamentals of a fair hearing must remain inviolate if the administrative adjudications are to be valid, and likewise the Califorma Supreme Court has said that the arbitration hearing must be fairly conducted. ${ }^{37}$ In this context the treatment accorded official notice in administrative adjudications becomes relevant for comparative purposes.

Official notice in administrative adjudications is recognized as one of the facts of life. ${ }^{38}$ But, it is submitted, the limit on official notice is the requirement of a fair

32 Gonzalez v. Gonzalez, 174 Cal. 588, 163 Pac. 993 (1917); see, e.g., Omaha v. Omaha Water Co., 218 U.S. 180 (1910) ; Gordon v. United States, 74 U.S. (7 Wall.) 188 (1868) ; Kentucky River Mills v. Jackson, 206 F.2d 111, 117 (6th Cir. 1953); Murray Oil Products Co. v. Mitsui \& Co., 146 F.2d 381, 383 (2d Cir. 1944); Carlston, Theory of the Arbitration Process, 17 LAW \& Contrearp. Prob. 631 (1952).

33 Cal. Code Civ. Proc. $\$ 1287$; see Sturges, Commercial Arbitrations and Awards, §§ 308-79 (1930).

34 The situation in the Griffith case exenplifies this championing. There, for example, one party named its president as an arbitrator. Griffith Co. v. San Diego College for Wonien, 280 P.2d 203, 215 (Cal. App. 1955). See American Eagle Fire Ins. Co. v. New Jersey Ins. Co., 240 N.X. 398, 405, 148 N.E. 562, 564 (1925) (articulate criticism of usual tripartite selection); Petrol Corp. v. Groupement D'Achat des Car, 84 F. Supp. 446 (S.D. N.Y. 1949) (tripartite panel rationalized as resulting in two advocates and one umpire); Popkin, Practical Problems Confronting the Practicing Lawyer, 17 LAw \& ConteMP. Prob. 652, 654 (1952); Note, The Use of Tripartite Boards in Labor, Commercial, and International Arbitration, 68 HARv. L. REV. 293 (1954). For suggestions of an alternative method of selection utilized by the American Arbitration Association, see KeIIor, ARBitration In Action 25-33 (1941).

35 Administrative Procedure Act $\S 7$ (c), 60 STAT. 243 (1946), 5 U.S.C. $\S 1006$ (c) (1952); see Judicial Councri of CaIIfornia, Tente Biennial Report 21-23, 94-103 (1944); cf. Davis, Evidence, 30 N.Y.U.L. REv. 1309 (1955).

36 See, e.g., Sapp v. Barenfeld, 34 Cal. 2d 515, 520, 212 P.2d 233, 237 (1949) ; Pacific Vegetable Oil Corp. v. C.S.T., Ltd., 29 Cal. 2d 228, 174 P.2d 441 (1946); In re Connor, 128 Cal. 279, 60 Pac. 862 (1900).

37 Sapp v. Barenfeld, 34 Cal. 2d 515, 520, 212 P.2d 233, 237 (1949); see Kagel, Labor and Commercial Arbitration Under the California Arbitration Statute, 38 CALIF. L. Rev. 799, 822-23 (1950). For a discussion of problems related to the vexatious related question of why must the hearing be "fair" in a private voluntary association, see Note, Exhaustion of Remedies in Pri-

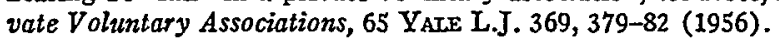

38 CAL. GOVT. CODE $\$ 11515$ provides: "In reaching a decision official notice nray be taken either before or after submission of the case for decision, of any generally accepted technical or scientific matter within the agency's special field, and of any fact which nua be judicially noticed by the courts of this State. Parties present at the hearing shall be informed of the matters to be noticed, and those inatters shall be noted in the record, referred to therein, or appended thereto. Any such party shall be given a reasonable opportunity on request to refute the officially noticed matters by evidence or by written or oral presentation of authority, the manner of such refutation to be determined by the agency." See JUdICIAI CouncII of CaIIFornta, Tente Bienniat Report 23, 107-12 (1944).

Administrative Procedure Act $\S 7$ (d), 60 STAT. 243 (1946), 5 U.S.C. $\S 1006$ (d) (1952) provides in part: "Where any agency decision rests on official notice of a material fact not appearing in the evidence in the record, any party shall on timely request be afforded an opportunity to show the contrary." See U.S. Commssion on ORganization of THE EXecutive Branch of the Goverament, Task Force Report on Legal Services and Procedure 199 (Recommendation No. 47) (1955). 
hearing, and the cardinal principle of fair hearing is that the parties have an opportunity to meet in appropriate fashion any materials that influence the ultimate decision. ${ }^{39}$ The United States Supreme Court has made it clear in a number of decisions that a demial of this opportunity will invalidate the adjudication. In 1912 the Court considered the objection that an agency materially based its findings on an ex parte investigation and that the facts used had not been disclosed to the objecting party. Justice Holmes, speaking for the court, held the adjudication invalid saying: ${ }^{40}$

Such an investigation is quite different from a view by a jury taken with notice and subject to the order of a court, and different again from the question of the right of the [agency] ... to take notice of results reached by it in other cases, when its doing so is made to appear in the record and the facts thus noticed are specified ....

In another case in which the agency used information not available to the parties, the Court said: 41

The objection to the use of the data ... . is not lack of authenticity or untrustworthiness. It is that the [parties] ... . were left without notice of the evidence with which they were, in fact, confronted .... The requirement that in an adversary proceeding specific reference he made, is essential to the preservation of the substantial rights of the parties.

Both the Federal and the California Administrative Procedure Acts also give effect to these propositions. ${ }^{42}$

The "fundamentals of a fair hearing" test has also been applied by courts in arbitrations althougl the language of notice has not been used. In Omaka $v$. Omaka Water $\mathrm{Co}_{.3}^{.3}$ the Supreme Court considered the result of taking evidence through the ex parte investigations of an appraiser: ${ }^{44}$

If this was a technical arbitration ... to be heard and decided upon evidence submitted, the examination ... . would be such misconduct as would vitiate the award. In such a matter the rules relating to judicial inquiry would apply.

The leading and much quoted case in New York dealing with ex parte investigations is Stefano Berizzi Co. v. Krausz. ${ }^{45}$ There the arbitrator had taken some samples of the goods, the quality of which was in dispute, to the various important markets to inform himself of their quality. No notice was given to the parties, and on the strength of his personal investigation and the testimony given at the liearings, the arbitrator made his award. In vacating the award, Judge Cardozo, speaking for the court, said in respect to the nature of an arbitration under the statute: ${ }^{40}$

39 See Davis, Judicial Notice, 55 Colus. L. Rev. 945 (1955).

40 United States v. Baltimore \& O.S.W.R.R., 226 U.S. 14, 20 (1912).

41 United States v. Abilene \& S.R.R., 265 U.S. 274, 289 (1924); accord, Ohio Bell Tel. Co. v. Public Util. Comm'n, 301 U.S. 292, 301-05 (1937) ; St. Louis S.W.R.R. v. ICC, 264 U.S. 64 (1924) ; ICC v. Louisville \& N.R.R., 227 U.S. 88, 93 (1913). See also cases wherein draft boards used local panels in advisory capacity and the court required that the identity of the panels be disclosed and their advice made known to the party in order that the essentials of a fair trial be net. Eagles v. Saunuels, 329 U.S. 304, 313 (1946); United States v. Hearn, 153 F.2d 186, 189 (5th Cir. 1946); United States v. Cain, 149 F.2d 338, 341 (2d Cir. 1945).

42 See note 38 supra.

43218 U.S. 180 (1910). This is one of the authorities cited by the California Supreme Court in the Sapp case.

44 Id. at 198.

45239 N.Y. 315,146 N.E. 436 (1925), 34 Yare L.J. 905. See also Note, 25 Colum. L. Rev. 822,826 (1925); note 11 supra.

46239 N.Y. at 319,146 N.E. at 437. 
The declaration of [the arbitration statute] .... does not call for a relazation of restraints upon the conduct of the arbitrators in so far as those restraints have relation to the fundamentals of a trial and the primary conditions of notice and a hearing. Indeed, they are more important now than ever if arbitration is to obtain the full measure of its possibilities as an instrument of justice. ... If misbehavior be assumed we cannot doubt .... that prejudice resulted. The plaintiff, knowing nothing of the evidence, had no opportunity to rebut or even to explain it.

Subsequent cases relying on the rule of Stefano Berizzi Co. v. Krausz have also emphasized that the defect in ex parte collection of information lies in the lack of an opportunity for the party to explain or rebut. ${ }^{47}$ Courts of other jurisdictions have likewise lield that arbitrators going outside the evidence adduced at the hearing without notice to the parties constitutes misconduct sufficient to vacate the award.48 In such cases the usual requirement that the complaining party show prejudice to him is not applicable. The prejudice is assumed. ${ }^{49}$

Use by an arbitrator of his own knowledge as a material element in settling a dispute submitted to arbitration is subject to the same objection-the party is denied an opportunity to answer or rebut unless given notice of such use. But one of the advantages of arbitration is the submission of questions to arbitrators who are selected for their familiarity with the general field involved. ${ }^{50}$ If the parties agree to the use of such knowledge without notice to them, as when they agree to an arbitrator's ex parte investigation and consultation, there is no objection. ${ }^{51}$

-Had the California Supreme Court approached the problems posed in the Sapp and Griffith cases in the context of what constitutes a fair liearing, the results may well have been different. In the Sapp case the ex parte investigation went to a material aspect of the award: the amount of the damages. In the Griffith case an equally important fact was determined by the ex parte consultation: the applicable law and legal principles to be utilized by the arbitrator. In both situations the party to the submission was denied an opportunity to answer, question, or rebut the facts which the arbitrators, in essence, noticed officially. In both cases the facts so noticed bore directly on the issue in dispute and were material to the ultimate decision. In this light Justice Edmonds' dissent in Sapp on the ground that a fair trial was denied becomes persuasive. ${ }^{62}$

47 E.g., 290 Park Avenue, Inc. v. Fergus Motors, Inc, 275 App. Div. 565, 90 N.Y.S.2d 613 (1st Dep't 1949) ; E. Millius \& Co. v. Regal Shirt Corp., 113 N.Y.S.2d 385 (Sup. Ct. 1952); Saffir v. Wilson, 100 N.Y.S.2d 263 (Sup. Ct. 1950) ; In the Matter of Herman, 170 Misc. 852, 10 N.Y.S.2d 46 (Sup. Ct. 1938).

48 Tejas Development Co. v. McGough Bros., 165 F.2d 276 (5th Cir. 1947); Jessup \& Moore Paper Co. v. A. S. Reed \& Bro. Co., 10 Del. Ch. 146, 87 Atl. 1011 (Ch. 1913); Moshier v. Shear, 102 Ill. 169 (1882) ; Hewitt v. Reed City, 124 Mich. 6, 82 N.W. 616 (1900); Fred J Brotherton, Inc. v. Kreielsheimer, 8 N.J. 66, 83 A.2d 707 (1951); Seaboard Surety Co. v. Commonwealth, $350 \mathrm{~Pa} .87,38$ A.2d 58 (1944).

40 See, e.g., text at note 45 supra.

50 Judge Learned Hand pointed out: "In trade disputes one of the chief advantages of arbitration is that the arbitrators can be chosen who are familiar with the practices and customs of the calling and with just such matters as what are current prices, what is merchantable quality, what are the terms of sale and the like." American Almond Products Co. v. Consolidated Pecan Sales Co., 144 F.2d 448, 450 (2d Cir. 1944); see Dampskibsselsk Dannebrog v. Strange \& Co., 1 F. Supp. 380, 381 (S.D.N.Y. 1932) ; Liggett v. Torrington Bldg. Co., 114 Conn. 425, 158 Atl. 917 (1932) ; Koeple v. E. Liethen Grain Co., 205 Wis. 75, 236 N.W. 544 (1931).

51 E.g., Twin Lakes Reservoir \& Canal Co. v. Platt Rogers, Inc, 112 Colo. 155, 147 P.2d 828 (1944); Robins Silk Mfg. Co. v. Consolidated Piece Dye Works, 251 N.Y. 87, 167 N.E. 181 (1929) ; Puget Sound Bridge \& Dredging Co. v. Lake Washington Shipyards, 1 Wash. 2d 401, 96 P.2d 257 (1939).

62 See note 10 supra. 


\section{Conclusion}

It is submitted that when the ex parte activities of arbitrators result in information that is material to the decision on the controversy submitted to them, the parties should have an opportunity to question, answer, or rebut the information so obtained. This requirement could be satisfied in the following manner: First, the arbitrators could be restricted to hearing evidence at the hearing and be prohibited from any ex parte activity. It has been suggested that should the arbitrators need more information or clarification they could so inform the parties to the submission. ${ }^{53}$ Should expert testimony be needed, the arbitrators might call such witness on their own initiative. Second, if outside investigation, consultation, and conscious use of an arbitrator's expert knowledge is permitted, the arbitrators could be required to so inform the parties of the information so acquired before the award is made, thus enabling answer, cross-examination, rebuttal, or the submission of additional evidence as the situation may require.

When the objection of ex parte activity without notice to the parties is presented to the reviewing court, it should also be tested against the requirement of a fair hearing. Should the court determine that a fair hearing was not had, it has the alternatives of vacating the award on the grounds of misconduct ${ }^{64}$ or vacating the award and in its discretion resubmitting the question to the arbitrators for a rehearing. ${ }^{55}$ The latter course would provide an effective means of handling the problem particularly from the standpoint of the parties who would be spared the time and expense of litigation or the initiation of a new arbitration proceeding.

William R. Berkman

53 Kagel, Labor and Commercial Arbitration Under the California Arbitration Stattite, 38 CALIF. L. REv. 799, 823 (1950) ; see Tejas Development Co, v. McGough Bros., 165 F.2d 276, 282 (5th Cir. 1947).

54 Cal. Code Crv. Proc. \$1288(c).

55 CaL. Code Crv. Proc. $\$ 1288$ provides in part: "Where an award is vacated and the time, within which the agreement required the award to be made, has not expired, the court may, in its discretion, direct a rehearing by the arbitrators." 